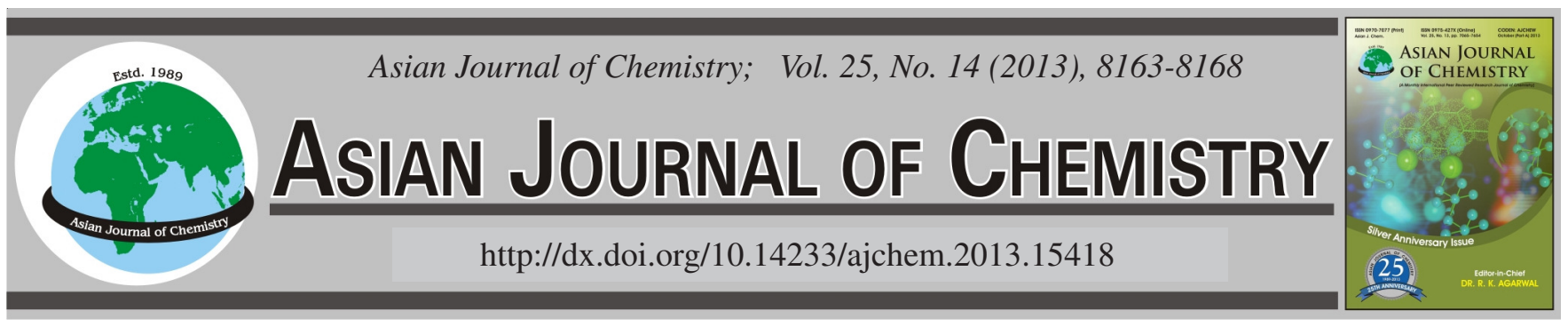

\title{
Nanostructured Composite Based on Polyaniline and Rice Raw for Removal of Lead(II) and Cadmium(II) from Solution
}

Phan Thi Binh ${ }^{1, *}$, Рham Thi Tot ${ }^{1}$, Mai Thi Thanh Thuy ${ }^{1}$, Mai Thi Xuan ${ }^{1}$, Bui Minh Quy ${ }^{2}$ and Nguyen The Duyen ${ }^{3}$

${ }^{1}$ Institute of Chemistry, Vietnam Academy of Science and Technology, 18 Hoang Quoc Viet, Hanoi, Vietnam

${ }^{2}$ Faculty of Chemistry, College of Sciences, Thai Nguyen University, Thainguyen, Vietnam

${ }^{3}$ Faculty of Chemistry, Hanoi Pedagogical University No 2, Vietnam

*Corresponding author: Fax: +84 43 8361283; Tel: +84 43 7564312; E-mail: phanthibinh@ich.vast.vn

(Received: 5 March 2013;

Accepted: 5 August 2013)

AJC-13896

\begin{abstract}
Composites based on polyaniline and raw rice were prepared by chemical method from acid medium containing aniline using ammonium persulfate as oxidation agent. The IR-spectrum confirmed the presence of polyaniline existed in composite which having morphological structure in nano scale by SEM and TEM images. Lead(II) and cadmium(II) ion concentrations in solution before and after adsorption process on absorbents were analyzed by atomic absorption spectroscopy. The favourable adsorption process of them was found by dimensionless Langmuir $\left(\mathrm{R}_{\mathrm{L}}\right)$ and Freundich parameter $\left(\mathrm{N}_{\mathrm{F}}\right)$. The maximum adsorption capacity obtained from the Langmuir isotherm model were 217.3913 and $138.8899 \mathrm{mg} / \mathrm{g}$ for $\mathrm{Pb}^{2+}$ and $\mathrm{Cd}^{2+}$, respectively. The negative $\Delta \mathrm{G}^{\circ}$ values were found indicating the feasibility and spontaneous nature of the adsorption process for them.
\end{abstract}

Key Words: Polyaniline-rice raw composite, Langmuir isotherm adsorption, Nanostructure, Heavy metal ions removal.

L - - - - - - - - - - - - - - - - - - - - - - - - - - - - - - - - - - -

\section{INTRODUCTION}

Many adsorbents based on zeolite, bentonite or conducting polymer composites, etc. have been using for removal of heavy metal ions from waste water ${ }^{1-3}$. In previous years, among conducting polymer, polyaniline (PANi) was mostly hybrided with agricultural waste or other materials to become composites using for environmental treatment because of their positive characteristics $^{4-6}$. Vietnam is a land of rice export so a huge amount of raw rice from which as an agricultural waste goes into environment. The aim of this work was preparation of composite based on raw rice with polyaniline for removing $\mathrm{Pb}^{2+}$ and $\mathrm{Cd}^{2+}$ ions from solution. The thermodynamic study and adsorption mechanisms of above metal ions were also studied.

\section{EXPERIMENTAL}

Preparation of materials: Composite was prepared by chemical polymerizarion owing to oxidation of aniline in hydrochloric acid medium at presence of raw rice and ammonium persulfate. The reaction was occurred in $18 \mathrm{~h}$ under continuously stirring at $1-5^{\circ} \mathrm{C}$. After purification and changing it into emeraldine base (EB) by treatment with $0.5 \mathrm{M}$ ammonia solution, it was filtrated and dried under vacuum condition at $50^{\circ} \mathrm{C}$ in $2 \mathrm{~h}$ and then kept in a sealed bottle for material properties and adsorption ability of heavy metal ions.
Detection method: The structure of materials was carried out by infrared spectrum on IMPACT 410-Nicolet unit. The surface morphology of them was examined by SEM on an equipment FE-SEM Hitachi S-4800 (Japan) and TEM on a Jeol 200CX (Japan). Their crystaline structure was analyzed by using an X-ray diffractometer D5000- Siemens (Germany). Their adsorption ability of heavy metal ions was characterized by atom adsorption spectroscopy (AAS) on an equipment Shimadzu AA-6800 (Japan).

Procedure of adsorption research: The mixture of absorbent and solution containing heavy metal ion were swinged at $300 \mathrm{rpm}$ for $40 \mathrm{~min}$ and then filtered to remove solid parts. The filtrate was analyzed by AAS.

The amount of solute removed at equilibrium can caculate following equation:

$$
\mathrm{q}=\frac{\left(\mathrm{C}_{0}-\mathrm{C}\right) \times \mathrm{V}}{\mathrm{m}}
$$

where $\mathrm{C}_{\mathrm{o}}$ is initial concentration, $\mathrm{C}$ is concentration after adsorption, $\mathrm{V}$ is amount of solution and $\mathrm{m}$ is adsorbent dose.

\section{RESULTS AND DISCUSSION}

SEM images: The images illustrated in Fig. 1 showed that obtained composite existed in nanostructural fibres having not uniform diameter (c) in comparision with which of polyaniline (b). Raw rice had spongy structure formed by 


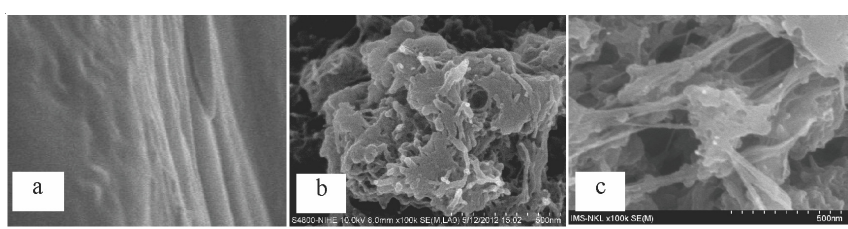

Fig. 1. SEM images of raw rice (a), polyaniline (b) and composite prepared with ratio between monomer and raw rice of $1: 2$

mixing fibres of cellulose, hemicellulose and lignin containing materials.

TEM images: TEM images (Fig. 2) showed two clearly differrent colours the light one belonging to polyaniline enclosing the dark one belonging to raw rice. Both of them had size in nano range. The obtained results from SEM and TEM analysis explained that nanostructural composite based on polyaniline and raw rice were succesfully prepared in present research.

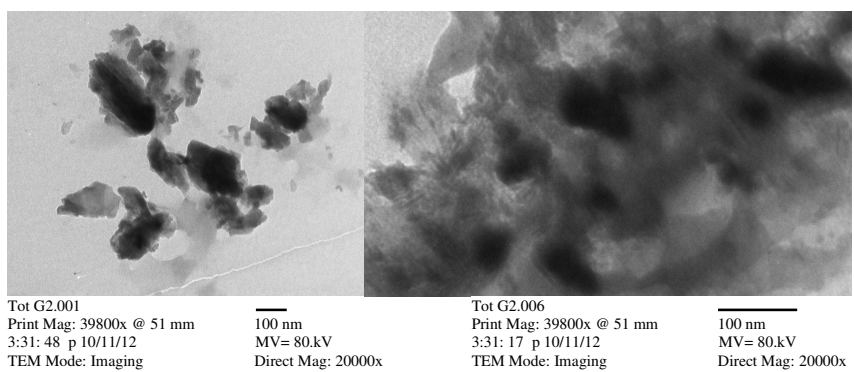

Fig. 2. TEM images of composite prepared with ratio between monomer and raw rice of $1: 2$
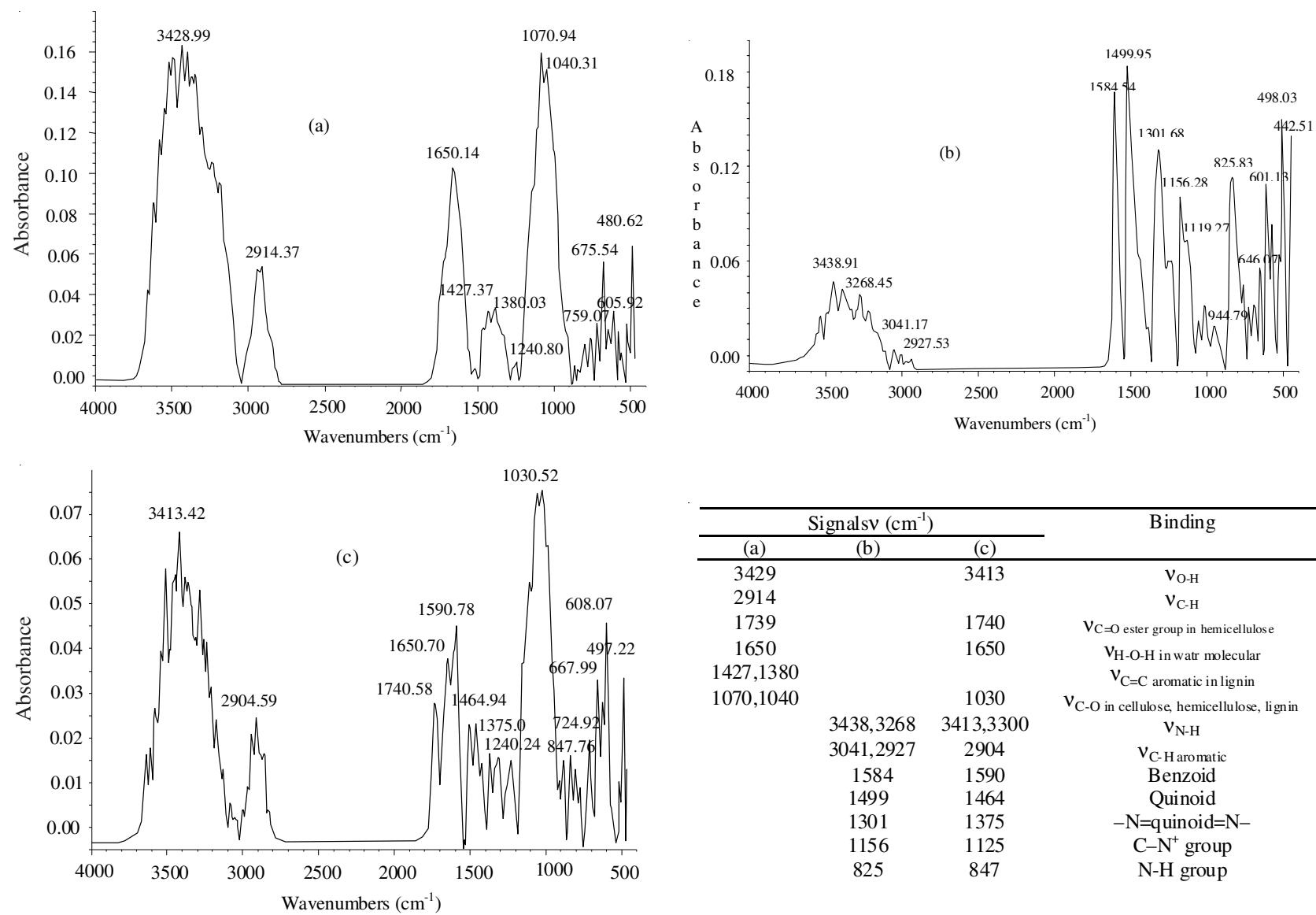

\begin{tabular}{cccc}
\hline \multicolumn{3}{c}{ Signalsv $\left(\mathrm{cm}^{-1}\right)$} & Binding \\
\hline (a) & (b) & (c) & \\
\hline 3429 & & 3413 & $\mathrm{v}_{\mathrm{O}-\mathrm{H}}$ \\
2914 & & & $\mathrm{v}_{\mathrm{C}-\mathrm{H}}$ \\
1739 & & 1740 & $\mathrm{v}_{\mathrm{C}=\mathrm{O} \text { ester group in hemicellulose }}$ \\
1650 & & 1650 & $\mathrm{v}_{\mathrm{H}-\mathrm{O}-\mathrm{H} \text { in watr molecular }}$ \\
1427,1380 & & & $\mathrm{v}_{\mathrm{C}=\mathrm{C} \text { aromatic in lignin }}$ \\
1070,1040 & & 1030 & $\mathrm{v}_{\mathrm{C}-\mathrm{O} \text { in cell ulose, hemicellulose, lignin }}$ \\
& 3438,3268 & 3413,3300 & $\mathrm{v}_{\mathrm{N}-\mathrm{H}}$ \\
& 3041,2927 & 2904 & $\mathrm{v}_{\mathrm{C}-\mathrm{H} \text { aromatic }}$ \\
& 1584 & 1590 & Benzoid \\
& 1499 & 1464 & Quinoid \\
& 1301 & 1375 & $-\mathrm{N}=\mathrm{quinoid}=\mathrm{N}-$ \\
& 1156 & 1125 & $\mathrm{C}-\mathrm{N}^{+}$group \\
& 825 & 847 & $\mathrm{~N}-\mathrm{H}$ group
\end{tabular}

Fig. 3. IR-spectra of (a) raw rice, (b) polyaniline and (c) polyaniline-raw rice composite prepared with ratio between monomer and raw rice of $1: 2$ 

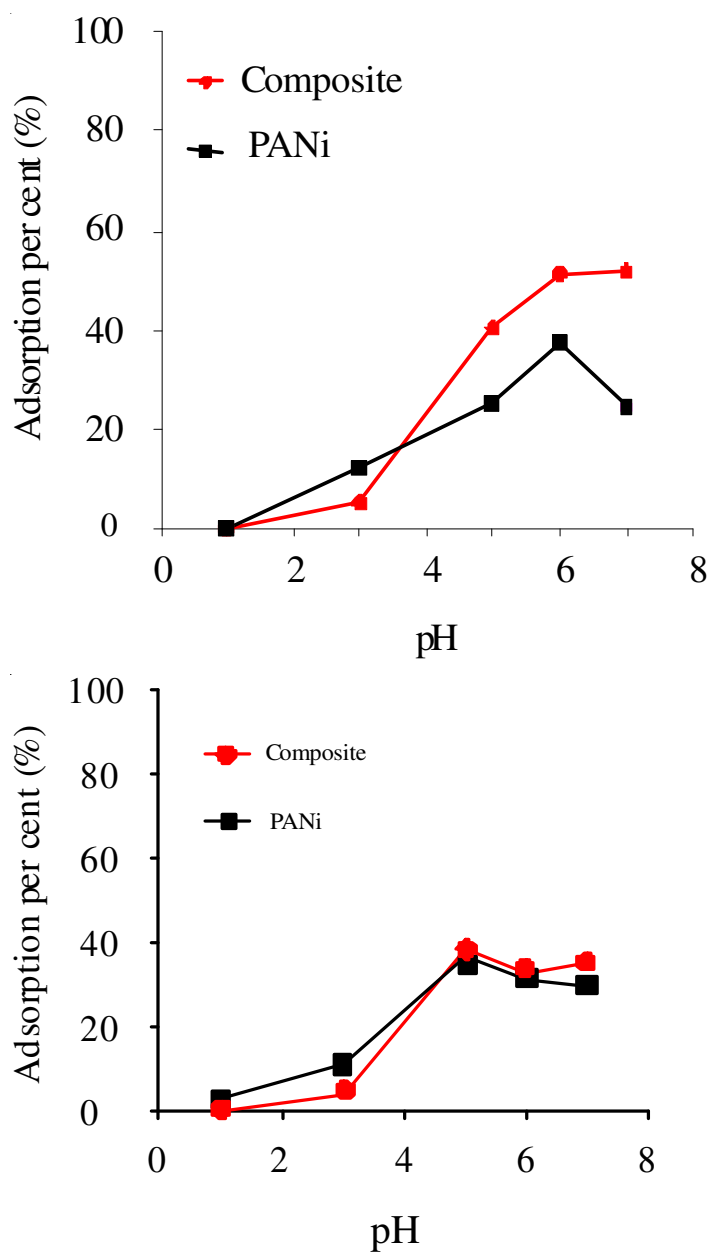

Fig. 4. Influence of $\mathrm{pH}$ on adsorption ability of $\mathrm{Pb}^{2+}$ (above) and $\mathrm{Cd}^{2+}$ ions (below) onto adsorbents. Initial concentration of $\mathrm{Pb}^{2+}=20 \mathrm{mg} / \mathrm{L}$ and $\mathrm{Cd}^{2+}=15 \mathrm{mg} / \mathrm{L}$

Influence of initial concentration: The removal ability of metal ions from solution depended decreasingly on their initial concentration among them lead ion can be removed by composite better than that by polyaniline in comparision with cadmium ion (Fig. 5).

Effect of contact time: The adsorption capacity and removal per cent for $\mathrm{Cd}^{2+}$ and $\mathrm{Pb}^{2+}$ were evaluated following contact time at $\mathrm{pH}$ of 5 and 6 for $\mathrm{Cd}^{2+}$ and $\mathrm{Pb}^{2+}$ ions, respectively. It reached the maximum value of $130 \mathrm{mg} / \mathrm{g}$ for $\mathrm{Pb}^{2+}$

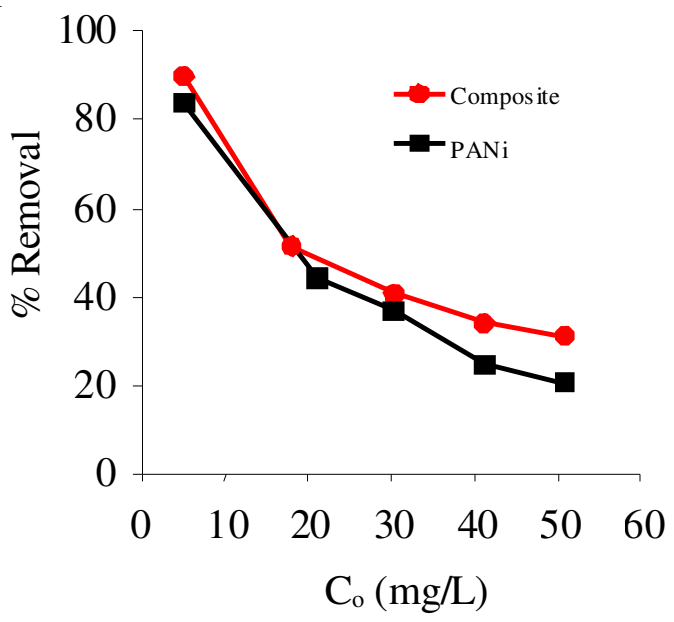

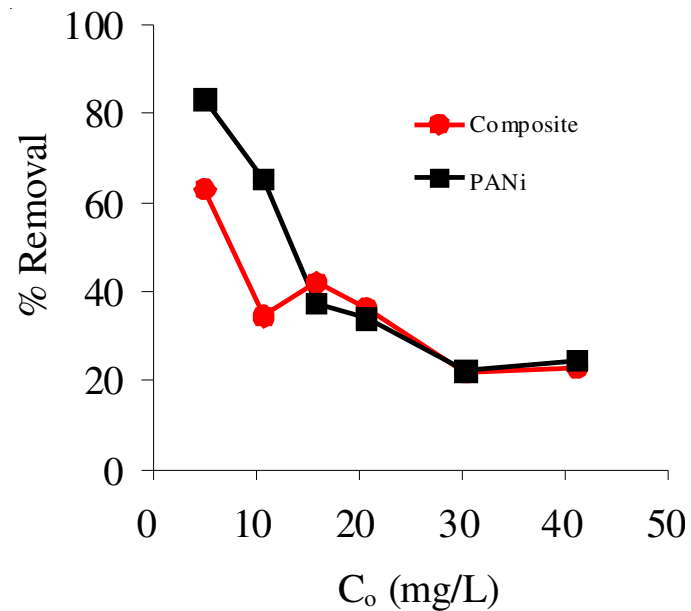

Fig. 5. Influence of initial concentration of $\mathrm{Pb}^{2+}$ (above) and $\mathrm{Cd}^{2+}$ ions (below) on removal ability of them from solution by adsorbents

and $76.2667 \mathrm{mg} / \mathrm{g}$ for $\mathrm{Cd}^{2+}$ ions after contact time of $40 \mathrm{~min}$, after which the removal effect was also optimal for both ions. However, the removal effect for $\mathrm{Pb}^{2+}$ was higher than that for $\mathrm{Cd}^{2+}$ in the same time (Fig. 6).

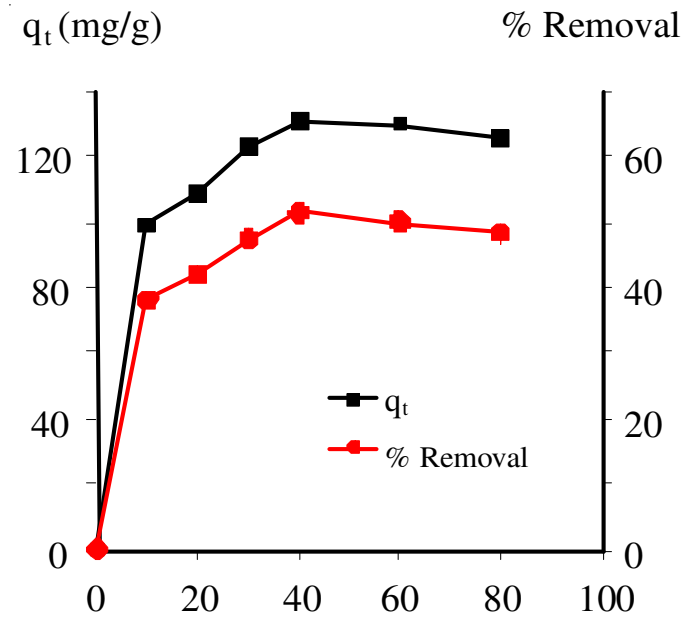

Time (min)

$\mathrm{q}_{\mathrm{t}}(\mathrm{mg} / \mathrm{g}) \quad \%$ Removal

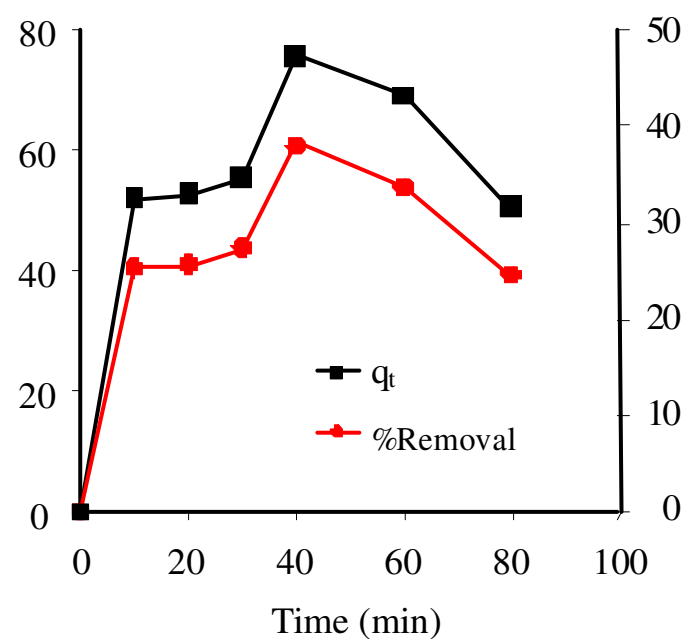

Fig. 6. Influence of contact time on adsorption capacity and removal per cent for $\mathrm{Pb}^{2+}$ (above) and for $\mathrm{Cd}^{2+}$ ions (below) onto composite. Conditions for $\mathrm{Pb}^{2+}: \mathrm{pH}=6$ and $\mathrm{C}_{\mathrm{o}}=18.5 \mathrm{mg} /$; for $\mathrm{Cd}^{2+}: \mathrm{pH}=5$ and $\mathrm{C}_{\mathrm{o}}=14.93 \mathrm{mg} / \mathrm{L}$ 
Langmuir model: Langmuir model can be expressed by eqn. 3:

$$
\frac{\mathrm{C}}{\mathrm{q}}=\frac{1}{\mathrm{q}_{\max } \mathrm{K}_{\mathrm{L}}}+\frac{\mathrm{C}}{\mathrm{q}_{\max }}
$$

where $\mathrm{q}$ is the amount of solute removed at adsorbed equilibrium, $\mathrm{C}$ is concentration after adsorption, $\mathrm{q}_{\max }$ is maximum adsorption capacity of absorbents, $\mathrm{K}_{\mathrm{L}}$ is Langmuir parameter. Fig. 7 showed that the Langmuir isotherm parameters given in Tables 1 and 2 for $\mathrm{Pb}^{2+}$ and $\mathrm{Cd}^{2+}$ ions, respectively. It explained that the maximum adsorption capacity of composite better than that of polyaniline for both regarded ions among them the $\mathrm{q}_{\max }$ of composite for $\mathrm{Pb}^{2+}$ ion $(217.3913 \mathrm{mg} / \mathrm{g}$ ) was much higher than that for $\mathrm{Cd}^{2+}$ ion $(138.8899 \mathrm{mg} / \mathrm{g})$.
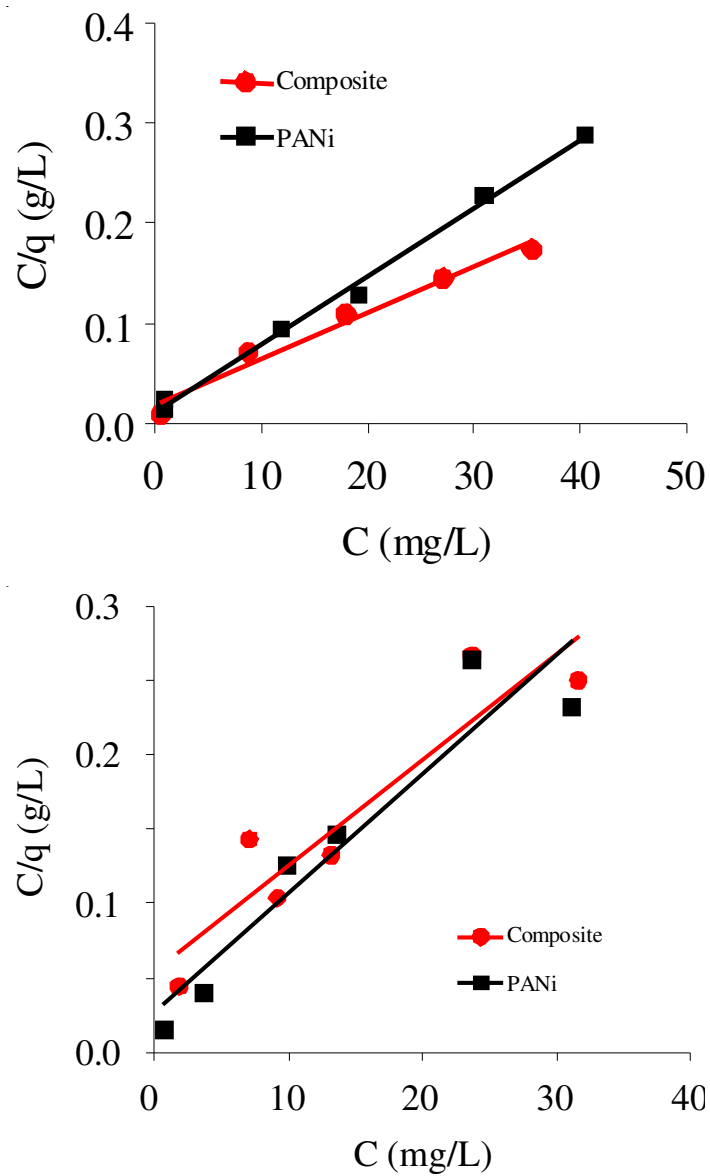

Fig. 7. Langmuir model of $\mathrm{Pb}^{2+}\left(\right.$ above, $\mathrm{pH}=6$ ) and $\mathrm{Cd}^{2+}$ ions (below, $\mathrm{pH}$ $=5$ ) onto adsorbents

\begin{tabular}{lcccc} 
& \multicolumn{5}{c}{ TABLE 1} \\
& \multicolumn{4}{c}{ ADSORPTION PARAMETER FOR } \\
& $\mathrm{Pb}^{2+}$ ONTO MATERIALS $(\mathrm{pH}=6)$ \\
\hline Materials & $\begin{array}{c}\mathrm{q}_{\max } \\
(\mathrm{mg} / \mathrm{g})\end{array}$ & $\mathrm{R}^{2}$ & $\begin{array}{c}\mathrm{K}_{\mathrm{L}} \\
(\mathrm{L} / \mathrm{mg})\end{array}$ & Langmuir equation \\
\hline PANi & 147.6588 & 0.9958 & 0.623853 & $\mathrm{y}=0.0068 \mathrm{x}+0.0109$ \\
Composite & 217.3913 & 0.9738 & 0.235897 & $\mathrm{y}=0.0046 \mathrm{x}+0.0195$ \\
\hline
\end{tabular}

\begin{tabular}{lcccc}
\multicolumn{5}{c}{ TABLE 2 } \\
& \multicolumn{5}{c}{ ADSORPTION PARAMETER FOR } \\
& $\mathrm{Cd}^{2+}$ ONTO MATERIALS $(\mathrm{pH}=5)$ \\
\hline Materials & $\begin{array}{c}\mathrm{q}_{\max } \\
(\mathrm{mg} / \mathrm{g})\end{array}$ & $\mathrm{R}^{2}$ & $\begin{array}{c}\mathrm{K}_{\mathrm{L}} \\
(\mathrm{L} / \mathrm{mg})\end{array}$ & Langmuir equation \\
\hline PANi & 123.4568 & 0.8946 & 0.321429 & $\mathrm{y}=0.0081 \mathrm{x}+0.0252$ \\
Composite & 138.8899 & 0.8569 & 0.134831 & $\mathrm{y}=0.0072 \mathrm{x}+0.0534$ \\
\hline
\end{tabular}

By expressing of dimensionless Langmuir parameter $\mathrm{R}_{\mathrm{L}}$ as the isotherm shape following eqn. 4 that can predict if an adsorption system is favourable or not ${ }^{9,10}$ :

$$
\mathrm{R}_{\mathrm{L}}=\frac{1}{1+\mathrm{K}_{\mathrm{L}} \mathrm{xC}_{0}}
$$

According to Ghorbani et al. ${ }^{10}$ and Mamdouth et al. ${ }^{11}$, if $\mathrm{R}_{\mathrm{L}}>1$ the adsorption process is unfavourable, $\mathrm{R}_{\mathrm{L}}=1$ it is linear, $\mathrm{R}_{\mathrm{L}}=0$ it is irreversible and $0<\mathrm{R}_{\mathrm{L}}<1$, it is favourable. The parameter $R_{L}$ given in Tables 3 and 4 indicated the adsorption process of $\mathrm{Pb}^{2+}$ and $\mathrm{Cd}^{2+}$ ions on mentioned adsorbents is favourable because of $0<\mathrm{R}_{\mathrm{L}}<1$.

TABLE-3

VALUES OF DIMENSIONLESS LANGMUIR PARAMETER $\mathrm{R}_{\mathrm{L}}$ FOR Pb $\mathrm{Pb}^{2+}$ ION ADSORPTION

\begin{tabular}{ccc}
\hline \multirow{2}{*}{$\mathrm{C}_{\mathrm{o}}(\mathrm{mg} / \mathrm{L})$} & \multicolumn{2}{c}{$\mathrm{R}_{\mathrm{L}}(\mathrm{L} / \mathrm{mg})$} \\
\cline { 2 - 3 } & $\mathrm{PANi}$ & Composite \\
\hline 5.04 & 0.293421 & 0.456846 \\
21.19 & 0.241300 & 0.190616 \\
30.31 & 0.070326 & 0.122699 \\
41.16 & 0.050229 & 0.093375 \\
50.87 & 0.037484 & 0.076923 \\
\hline
\end{tabular}

TABLE-4

VALUES OF DIMENSIONLESS LANGMUIR PARAMETER $\mathrm{R}_{\mathrm{L}}$ FOR $\mathrm{Cd}^{2+}$ ION ADSORPTION

\begin{tabular}{ccc}
\hline \multirow{2}{*}{$\mathrm{C}_{\mathrm{o}}(\mathrm{mg} / \mathrm{L})$} & \multicolumn{2}{c}{$\mathrm{R}_{\mathrm{L}}(\mathrm{L} / \mathrm{mg})$} \\
\cline { 2 - 3 } & $\mathrm{PANi}$ & Composite \\
\hline 5.070 & 0.380279 & 0.377259 \\
10.808 & 0.223513 & 0.221294 \\
15.858 & 0.164009 & 0.162257 \\
20.682 & 0.130757 & 0.129305 \\
30.377 & 0.092902 & 0.091826 \\
41.114 & 0.070347 & 0.069512 \\
\hline
\end{tabular}

Freundlich model: The Freundlich isotherm model can be expressed following eqn. 5 :

$$
\mathrm{q}=\mathrm{K}_{\mathrm{F}} \mathrm{C}^{1 / \mathrm{N}_{\mathrm{F}}}
$$

where $\mathrm{q}$ is the amount of solute removed at adsorbed equilibrium, $\mathrm{C}$ is concentration after adsorption, $\mathrm{K}_{\mathrm{F}}$ and $\mathrm{N}_{\mathrm{F}}$ are Freundlich parameters.

It was found the highest Freundlich parameter $\mathrm{K}_{\mathrm{F}}$ for $\mathrm{Pb}^{2+}$ ( $71.1377 \mathrm{mg} / \mathrm{g}$ in Table-5) which was over two times as high as $\mathrm{Cd}^{2+}(32.0996 \mathrm{mg} / \mathrm{g}$ in Table-6) in the case of composite.

\begin{tabular}{lcccc}
\multicolumn{5}{c}{ TABLE-5 } \\
& $\begin{array}{c}\text { ADSORPTION PARAMETER FOR Pb }{ }^{2+} \\
\text { ONTO MATERIALS }(\mathrm{pH}=6)\end{array}$ \\
\hline Materials & $\begin{array}{c}\mathrm{K}_{\mathrm{F}} \\
(\mathrm{mg} / \mathrm{g})\end{array}$ & $\mathrm{N}_{\mathrm{F}}$ & $\mathrm{R}^{2}$ & $\begin{array}{c}\text { Freundlich } \\
\text { equation }\end{array}$ \\
\hline PANi & 51.0387 & 3.2300 & 0.9089 & $\mathrm{y}=0.3096 \mathrm{x}+1.7079$ \\
Composite & 71.1377 & 3.4662 & 0.9925 & $\mathrm{y}=0.2885 \mathrm{x}+1.8521$ \\
\hline
\end{tabular}

\begin{tabular}{lcccc}
\multicolumn{5}{c}{ TABLE-6 } \\
& $\begin{array}{c}\text { ADSORPTION PARAMETER FOR Cd }{ }^{2+} \\
\text { ONTO MATERIALS }(\mathrm{pH}=5)\end{array}$ \\
\hline Materials & $\begin{array}{c}\mathrm{K}_{\mathrm{F}} \\
(\mathrm{mg} / \mathrm{g})\end{array}$ & $\mathrm{N}_{\mathrm{F}}$ & $\mathrm{R}^{2}$ & $\begin{array}{c}\text { Freundlich } \\
\text { equation }\end{array}$ \\
\hline PANi & 61.1787 & 5.777 & 0.6792 & $\mathrm{y}=0.1731 \mathrm{x}+1.7866$ \\
Composite & 32.0996 & 2.6674 & 0.7915 & $\mathrm{y}=0.3749 \mathrm{x}+1.5065$
\end{tabular}


The obtained results explained that adsorption of $\mathrm{Pb}^{2+}$ ions fitted into both Langmuir and Freundlich isotherm models better than that of $\mathrm{Cd}^{2+}$ onto materials because of higher $\mathrm{R}^{2}$ values. It were found $1<\mathrm{N}_{\mathrm{F}}<5$ that confirmed the adsorption process was also favourable ${ }^{8,10}$ (Fig. 8).
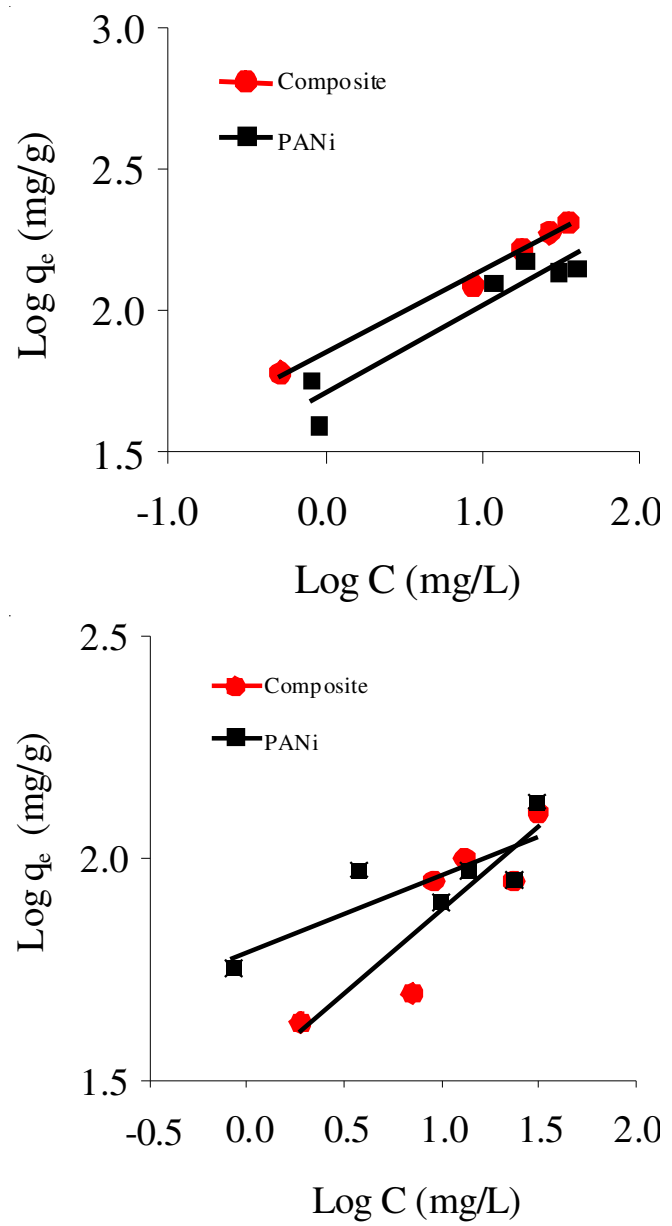

Fig. 8. Freundlich model of $\mathrm{Pb}^{2+}($ above, $\mathrm{pH}=6)$ and $\mathrm{Cd}^{2+}$ ion (below, $\mathrm{pH}$ $=5$ ) onto adsorbents

Thermodynamic study: The thermodynamic parameters such as standard Gibbs free energy $\Delta \mathrm{G}^{\mathrm{o}}(\mathrm{kJ} / \mathrm{mol})$ can be calculated from thermodynamic equilibrium constant $\mathrm{k}_{\mathrm{o}}$ following equation:

$$
\Delta \mathrm{G}^{\mathrm{o}}=-\mathrm{RT} \ln \mathrm{k}_{\mathrm{o}}
$$

The constant $\mathrm{k}_{\mathrm{o}}$ was determined by plotting $\ln \left(\mathrm{C}_{\mathrm{s}} / \mathrm{C}_{\mathrm{e}}\right)$ versus $\mathrm{C}_{\mathrm{s}}$ (Fig. 9) and extrapolating $\mathrm{C}_{\mathrm{s}}$ to zero ${ }^{12,13}$, where $\mathrm{C}_{\mathrm{e}}$ is the equilibrium concentration in solution $(\mathrm{mmol} / \mathrm{L})$ and $\mathrm{C}_{\mathrm{s}}$ is the solid-phase concentration at equilibrium ( $\mathrm{mmol} / \mathrm{g})$. $\mathrm{R}$ is the gas constant $(8.314 \mathrm{~J} / \mathrm{mol} \mathrm{K})$ and $\mathrm{T}$ is absolute temperature $(\mathrm{K})$.

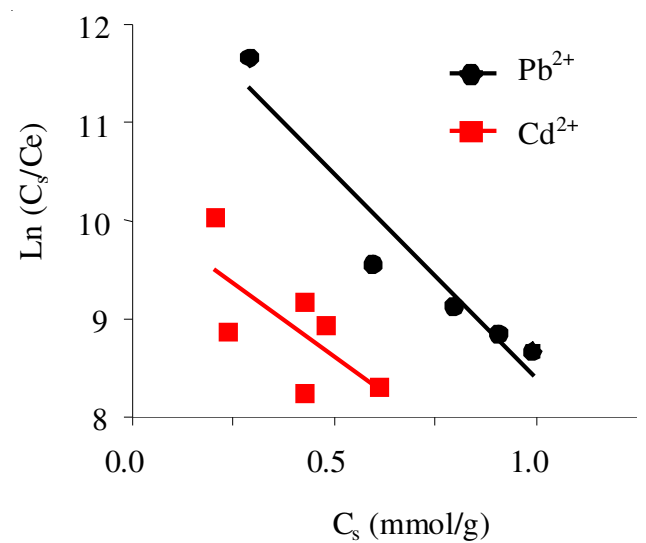

Fig. 9. Plots of $\ln \left(\mathrm{C}_{\mathrm{s}} / \mathrm{C}_{\mathrm{e}}\right)$ versus $\mathrm{C}_{\mathrm{s}}$ at room temperature $\left(30^{\circ} \mathrm{C}\right)$. Conditions: $\mathrm{pH}=6$ for $\mathrm{Pb}^{2+}$ and 5 for $\mathrm{Cd}^{2+}$ ions; absorbent: composite

At room temperature $\left(30^{\circ} \mathrm{C}\right)$ the negative $\Delta \mathrm{G}^{\mathrm{o}}$ values indicating the feasibility and spontaneous nature of the adsorption process for both involved metal ions among them $\mathrm{Pb}^{2+}$ ion can adsorb onto composite more easily than $\mathrm{Cd}^{2+}$ ion becauce of higher $\mathrm{k}_{\mathrm{o}}$ and negativer $\Delta \mathrm{G}^{\mathrm{o}}$ (Table-7).

\begin{tabular}{|c|c|c|}
\hline \multicolumn{3}{|c|}{$\begin{array}{l}\text { STANDARD GIBBS FREE ENERGY } \Delta \mathrm{G}^{\circ} \text { AND } \\
\text { THERMODYNAMIC QUILIBRIUM CONSTANT } \mathrm{k}_{\mathrm{o}} \text { FOR } \\
\text { METAL ION ADSORPTION ONTO COMPOSITE AT } \\
\text { ROOM TEMPERATURE }\left(30^{\circ} \mathrm{C}\right)\end{array}$} \\
\hline Metal ions & $\mathrm{k}_{\mathrm{o}}$ & $\Delta \mathrm{G}^{\mathrm{o}}(\mathrm{kJ} / \mathrm{mol})$ \\
\hline $\mathrm{Pb}^{2+}$ & 12.57 & -6.376 \\
\hline $\mathrm{Cd}^{2+}$ & 10.11 & -5.829 \\
\hline
\end{tabular}

Adsorption mechanisms: The interaparticle diffusion equation is decribed as:

$$
\mathrm{q}_{\mathrm{t}}=\mathrm{k}_{\mathrm{t}} \mathrm{t}^{0.5}+\mathrm{B}
$$

where $\mathrm{k}_{\mathrm{i}}$ is the intraparticle diffusion rate constant $\left(\mathrm{mg} \mathrm{g}^{-1}\right.$ $\min ^{-0.5}$ ) and $\mathrm{B}$ is the intercept. The detailed understanding of adsorption rate can be expressed by following factors: (i) diffusion of the solute from the bulk solution to the external surface of particle, (ii) diffusion from the surface to the internal sites (surface diffusion or pore diffusion) and (iii) adsorption on the interior sites of the adsorbent ${ }^{14-16}$.

According to this model, it were found three linear steps in Fig. 10 which illustrated the adsorption process of both $\mathrm{Pb}^{2+}$ and $\mathrm{Cd}^{2+}$ ions onto composite. The first stage is very sharp indicating the external surface adsorption. The second one is the gradual adsorption stage, where intraparticle diffusion is rate-controlled. Normally, the third one is the final equilibrium stage where intraparticle diffusion starts to slow down owing to extremely low adsorbate concentrations in the solution like in the case of $\mathrm{Pb}^{2+}$ ion, but, however, the desorption of $\mathrm{Cd}^{2+}$ ion may be occurred significantly after $40 \mathrm{~min}$ because of big

\begin{tabular}{|c|c|c|c|c|c|c|}
\hline \multirow{3}{*}{ Diffusion stage } & \multicolumn{6}{|c|}{$\begin{array}{l}\text { INTRAPARTICLE DIFFUSION COEFFICIENTS AND INTERCEPT VALUES FOR Pb }{ }^{2+} \\
\text { AND } \mathrm{Cd}^{2+} \text { ADSORPTION ONTO COMPOSITE AT ROOM TEMPERATURE }\left(30^{\circ} \mathrm{C}\right)\end{array}$} \\
\hline & \multicolumn{3}{|c|}{$\mathrm{Pb}^{2+}$} & \multicolumn{3}{|c|}{$\mathrm{Cd}^{2+}$} \\
\hline & $\mathrm{k}_{\mathrm{i}}\left(\mathrm{mg} \mathrm{g}^{-1} \min ^{0.5}\right)$ & $\mathrm{B}$ & $\mathrm{R}^{2}$ & $\mathrm{k}_{\mathrm{i}}\left(\mathrm{mg} \mathrm{g}^{-1} \min ^{0.5}\right)$ & $\mathrm{B}$ & $\mathrm{R}^{2}$ \\
\hline 1 & 31.2850 & 131.67 & 1 & 16.4020 & 0 & 1 \\
\hline 2 & 14.9140 & 45.454 & 1 & 12.5820 & -0.6743 & 0.8074 \\
\hline 3 & -0.2474 & $1 \mathrm{E}-14$ & 0.9981 & -1.1702 & 78.398 & 1 \\
\hline
\end{tabular}
negative slope of line appeared in this stage (Table-8). 

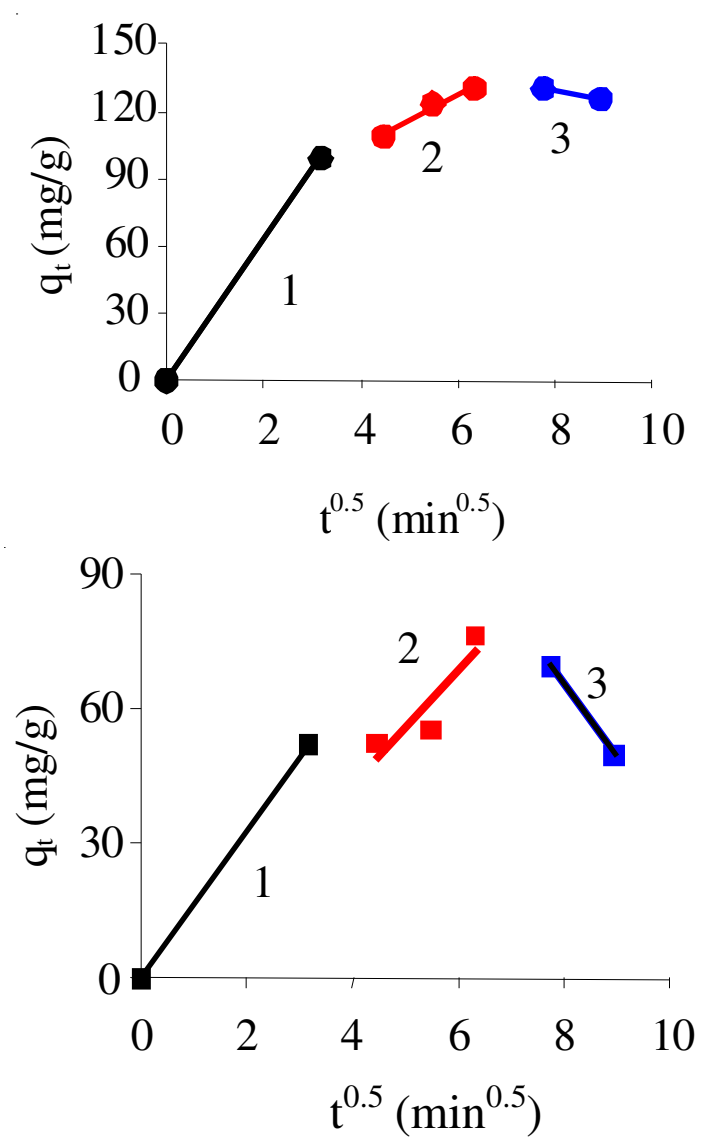

Fig. 10. Intraparticle diffusion plots for $\mathrm{Pb}^{2+}$ (above) and $\mathrm{Cd}^{2+}$ adsorption (below) onto composite at room temperature $\left(30{ }^{\circ} \mathrm{C}\right)$. Initial concentration of $\mathrm{Pb}^{2+}=18.5 \mathrm{mg} / \mathrm{L}(\mathrm{pH}=6)$ and $\mathrm{Cd}^{2+}=14.93 \mathrm{mg} / \mathrm{L}$ $(\mathrm{pH}=5)$

\section{Conclusion}

Nanostructured composite based on polyaniline and raw rice was successfully synthesized by chemical method. The adsorption ability of materials depended on $\mathrm{pH}$ medium which can receive values of 5 and 6 for an optimal adsorption process of both $\mathrm{Cd}^{2+}$ and $\mathrm{Pb}^{2+}$ ions, respectively. The adsorption of $\mathrm{Pb}^{2+}$ and $\mathrm{Cd}^{2+}$ ions onto present absorbents was favourable among them the adsorption of $\mathrm{Pb}^{2+}$ ion fitted into both Langmuir and Freundlich isotherm models better than $\mathrm{Cd}^{2+}$ ion. The maximum adsorption capacity were found 217.3913 and $138.8899 \mathrm{mg} / \mathrm{g}$ for $\mathrm{Pb}^{2+}$ and $\mathrm{Cd}^{2+}$ ions, respectively. The adsorption process of both ions onto composite is favourable among them the degree of spontaneity of $\mathrm{Pb}^{2+}$ is bigger than that of $\mathrm{Cd}^{2+}$ ion. The composite based on polyaniline and raw rice can use as adsorbent for above heavy metal treatment from solution.

\section{ACKNOWLEDGEMENTS}

This study was financially supported by VAST of Vietnam under code number VAST. ĐL.03/12-13.

\section{REFERENCES}

1. E. Erdem, N. Karapinar and R. Donat, J. Colloid Interf. Sci., 280, 309 (2004).

2. J.A. Hefne, W.K. Mekhemer, N.M. Alandis, O.A. Aldayel and T. Alajyan, Int. J. Phys. Sci., 3, 281 (2008).

3. F. Kanwal, R. Rehman, J. Anwar and M. Saeed, Asian J. Chem., 25, 2399 (2013).

4. R. Katal and H. Pahlavanzadeh, J. Vinyl Additive Technol., 17, 138 (2011).

5. R. Ansari and F. Raofie, E-J. Chem., 3, 35 (2006).

6. S.A. Ganai, H.T.N. Chishti, J. Ahmad and S. Ahmad, Am. J. Anal. Chem., 3, 272 (2012).

7. P.T. Binh, Macromol. Symp., 249-250, 228 (2007).

8. D.L. Liu, D.Z. Sun and Y.Q. Li, Sep. Sci. Technol., 46, 321 (2011).

9. M.B. Keivani, K. Zare, H. Aghaie and R. Ansari, J. Phys. Theoret. Chem. IAU Iran, 6, 59 (2009).

10. M. Ghorbani, H. Eisazadeh and A.A. Ghoreysh, Iran. J. Energy Environ., 3, 83 (2012).

11. N.N. Mamdouth, T.E. Kamar, E.E. Ebrahiem, H.M. Yehia and H.M. Mansour, Adsorp. Sci. Technol., 22, 25 (2004).

12. S. Babel and T.A. Kurniawan, Chemosphere, 54, 951 (2004).

13. C. Namasivayam, D. Prabha and M. Kumutha, Bioresour. Technol., 64, 77 (1998).

14. A. Findon, O. Mckay and H.S. Blair, J. Environ. Sci. Health A, 28, 173 (1993).

15. W.J. Weber and F.A. Digiano, Process Dynamics in Environmental Systems; Environmental Science and Technology Service, Wiley \& Sons, New York, pp. 89-94 (1996).

16. P. Chingombe, B. Saha and R.J. Wakeman, J. Colloid Interf. Sci., 302, 408 (2006). 